\title{
Design of Waste Treatment Applications at PT. Rifansi Dwi Putra Using Visual Basic.Net and MySQL Database
}

\author{
Miftahul Jannah, ${ }^{1,}$, Jenny Rosalina², Erliza Yubarda ${ }^{3}$
}

1,2,3AMIK Mitra Gama, Duri, Indonesia

\begin{tabular}{l} 
Article Information \\
\hline Article History: \\
Accepted by the Editor: May 31, 2021 \\
Final Revision: June 29, 2021 \\
Published Online: June 30, 2021 \\
Keywords \\
\hline Waste \\
Visual Basic \\
MySQL \\
Waterfall \\
Correspondence
\end{tabular}

E-mail: miiftahuljannah32@gmail.com*

\begin{abstract}
A B S T R A C T
PT. Rifansi Dwi Putra is a company that operates in the Oil and Gas Industry, especially in the Waste Handling Transportation (WHT) Project regarding Waste Transportation. PT. Rifansi Dwi Putra especially at the Sand Management Facility (SMF) in processing waste volume data already uses a computer and is supported by Microsoft Excel software. However, doing data input, searching, processing, and reporting takes a relatively long time. So that the resulting information is less accurate, thus requests for fast and accurate information are often late in presenting their reports. In this regard, to facilitate the process of data accuracy, it is better to create an application for data collection of waste volumes using Visual Basic Programming Language and MySQL database. To facilitate the operations department, especially in recording the volume of waste transported to the Sand Management Facility (SMF) and making reports on the volume of waste to control, repair, and process data based on information technology and help the obstacles faced. To produce applications in waste volume data collection to facilitate structured data input in the data entry process, make it easier to search waste volume data, and help the management team produce accurate waste volume reports, making it easier to make decisions. The user of this application is only owned by one person because it is still a single user or stand alone (desktop-based) and this application produces three reports, namely reports per day, reports per month and reports per unit.
\end{abstract}

\section{Introduction}

Information technology has coexisted in almost all areas of life, ranging from educational activities, economics, industry, services, health, transportation, banking and so on [1]. Technology has rapidly influenced the management of a company and the accounting information system in a business organization. This development shows that information technology has become a demand to meet every employee of the company [2].

PT. Rifansi Dwi Putra is engaged in the Oil and Gas Industry, especially in the Waste Handling Transportation (WHT) Project, namely the Transportation of Oil and Gas Waste. Waste is waste whose presence is no longer used by the environment because it has no useful and economic value. Waste that is disposed of can be in the form of solid, liquid or gaseous waste. Generally, waste has three types: organic, inorganic, and B3 (Toxic and Hazardous Materials). The waste transported at this company is a type of B3 waste originating from various kinds of toxic chemicals, namely oily sand waste [3]. 
PT. Rifansi Dwi Putra in processing waste volume data already uses computers and software, one of which is using the Microsoft Excel application. In conducting observations and interviews with the leadership of PT. Rifansi Dwi Putra, the problem that has been encounter in this research are inputting waste transport data, many errors occurred, searching for data was very long because the data was not stored in a systematic and grouped manner so that the administration department needed time and was inefficient, and reporting itself takes a relatively long time. So that the resulting information is less accurate, thus requests for fast and accurate information are often late in presenting their reports. Suppose this problem is left unchecked, the productivity of PT. Rifansi Dwi Putra is getting worse. So we need a waste data processing application at PT. Rifansi Dwi Putra who can make it easier for the operations department, especially in recording the volume of waste transported to the Sand Management Facility (SMF) and making reports on the volume of waste to control, repair and process data based on information technology and help the obstacles faced.

\section{Method}

To develop the design of information systems, the authors use research methods. The research method used is field research (field research) with methods in interviews and observations. The interview method is useful for obtaining all the data needed by asking questions directly to the owner of the company PT Rifansi Dwi Putra. In the observation method, data were collected by observing directly at PT. Rifansi Dwi Putra to obtain information related to waste processing data problems.

The system development method used is the System Development Life Cycle (SDLC). SDLC is useful for presenting the system development stage divided into five activities: requirements analysis, software design, implementation and unit testing, system integration, and maintenance of the information system used [4]. System Development Life Cycle is a process of developing or improving an application software system using models and methodologies based on well-tested methods [5]. The SDLC method used in this study is the waterfall. Figure 1 below is the waterfall stage.

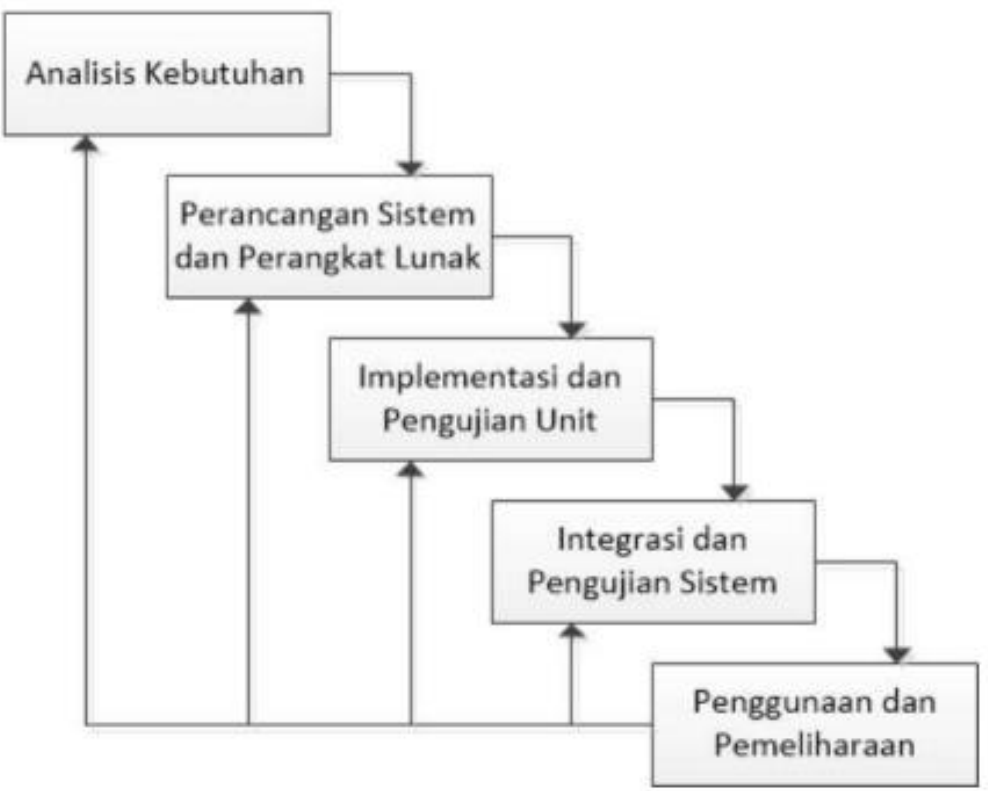

Figure 1. Waterfall Model

\section{Results and Discussion}

\section{1. $\quad$ Needs Analysis}

Problem analysis is carried out as an initial step that must be done before designing a system. By analyzing the problem, it will be known how important the information system to be designed is - design of 
waste treatment applications at PT. Rifansi Dwi Putra uses Visual Basic.Net and MySQL database. In addition, during the problem analysis stage, it is necessary to prepare the software and hardware used. After the research model has been determined, it is later applied according to the stages prepared in the initial step.

At the stage of analyzing user needs for the system, researchers observed PT. Rifansi Dwi Putra, especially in the administration of waste management, explores various information related to system problems that occur in waste data processing and analyzes the need for improvements to existing systems. This information mining activity is carried out by interviewing and direct observation of admins and leaders who are directly involved in processing waste data, collecting all supporting documents related to information systems such as employee data, waste processing data, and waste data processing reports.

\subsection{System and Software Design}

System design is a process that focuses on creating application programs including data structures, information system architecture, interface representations, and system coding procedures. This stage translates application requirements from the requirements analysis stage to a design display representation to be applied to a program at a later stage.

The waste treatment information system analysis is divided into four actors, namely: HE Admin, Loadchecker, Foreman, and Supervisor who have different roles. Figure 2 below is an analysis of the old information system.

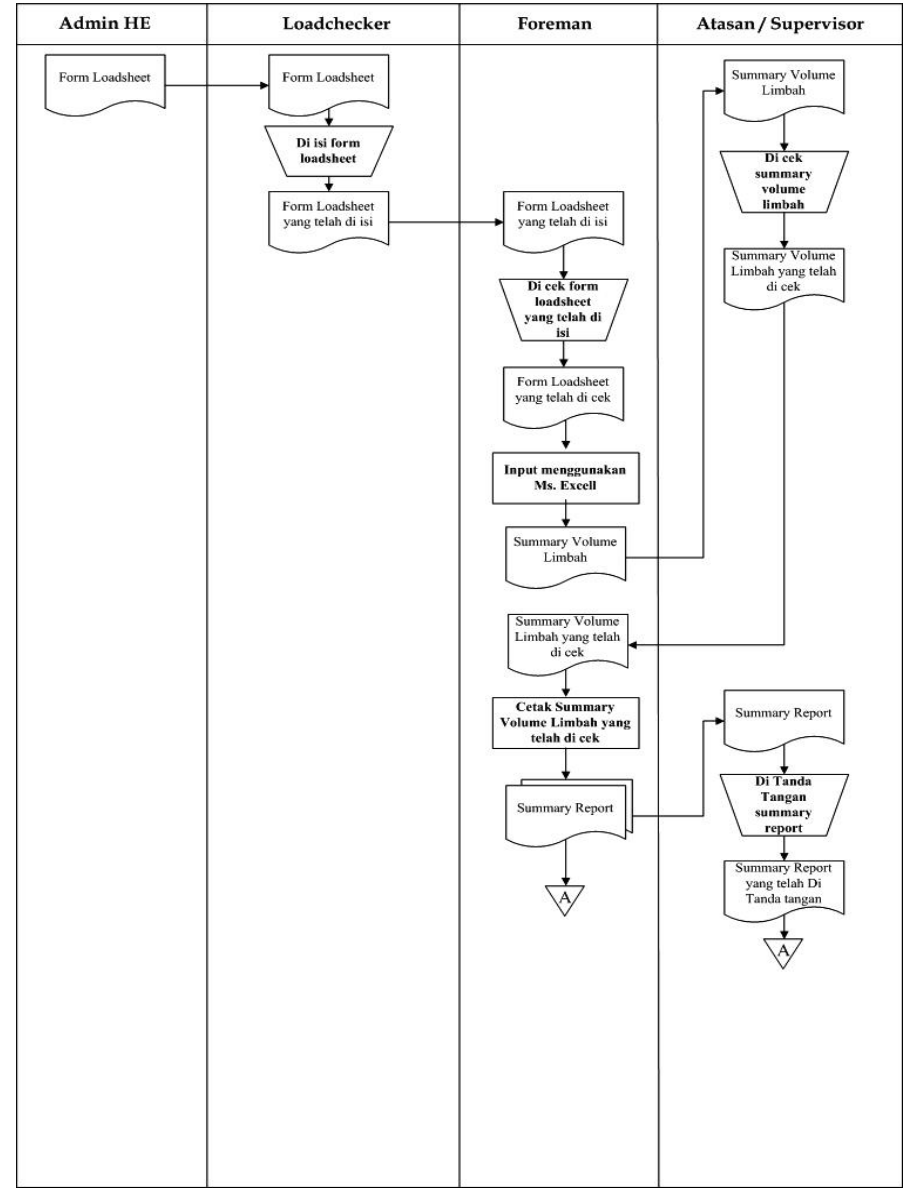

Figure 2. Analysis of Old Information Systems

After describing the analysis of the old information system, a new information system analysis is designed to result from changes from the previous information system flow where the initial process using 
Microsoft Excel was replaced to be integrated in a database. Figure 3 is an analysis of the new information system.

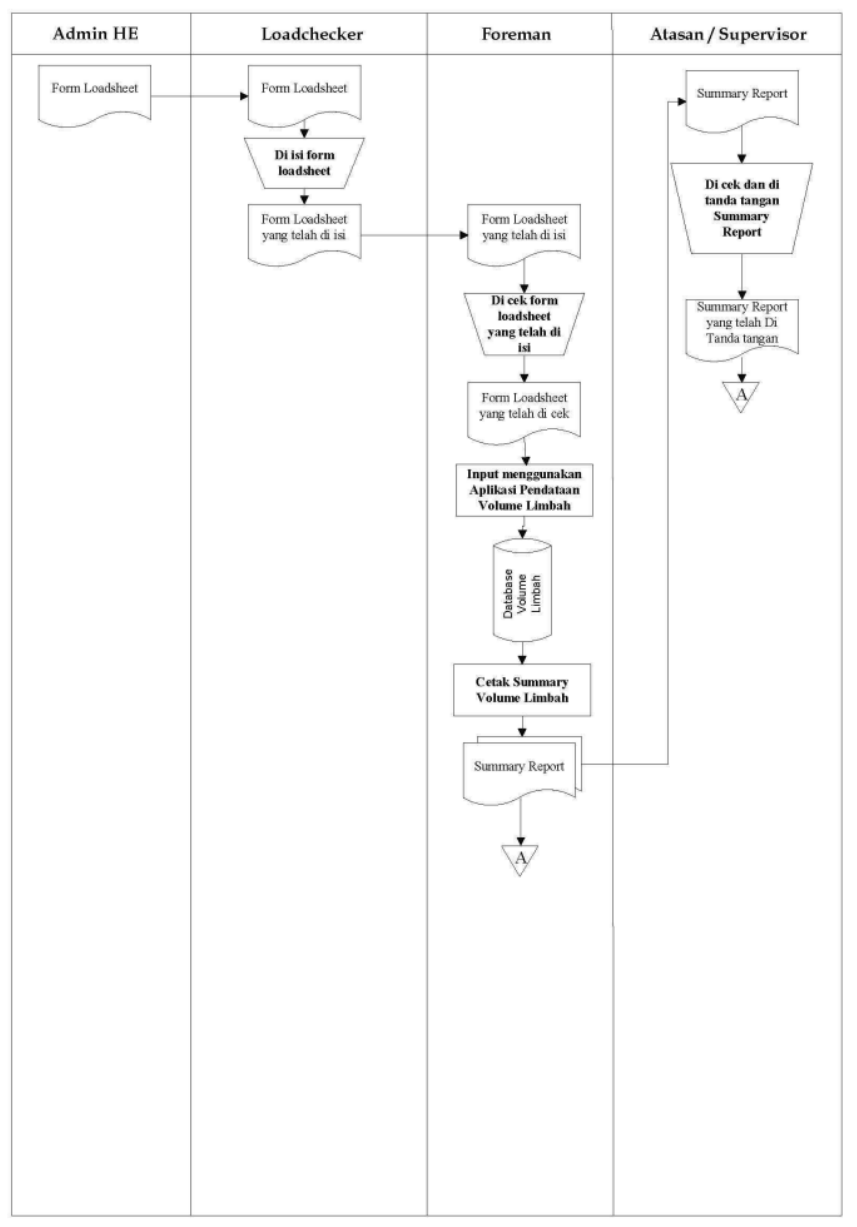

Figure 3. Analysis of New Information Systems

The interface design in this application begins with designing the login form. Figure 4 is the page for the login form.

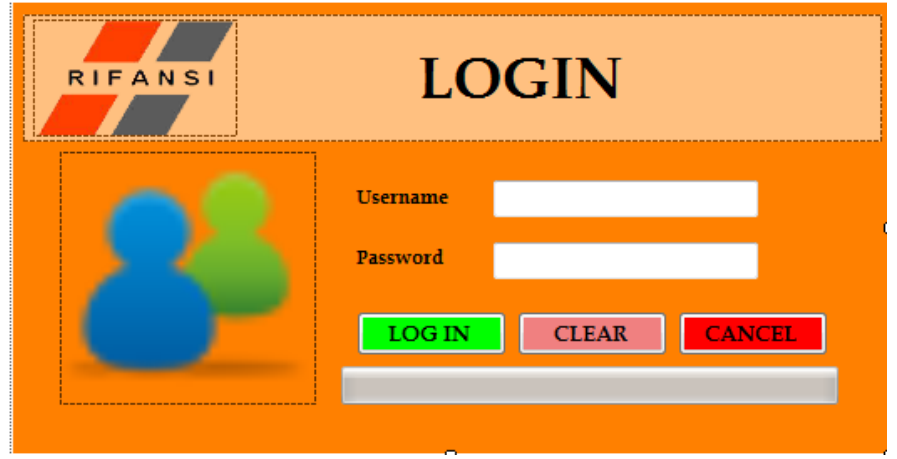

Figure 4. Login page

The main menu in this application is shown in Figure 5 below. 


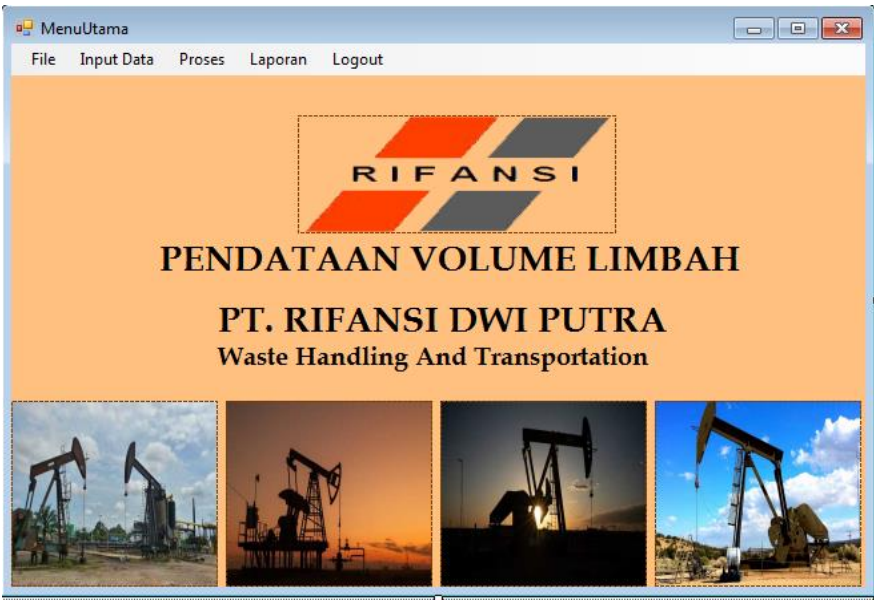

Figure 5. Main Page

The admin data form is shown in Figure 6 below.

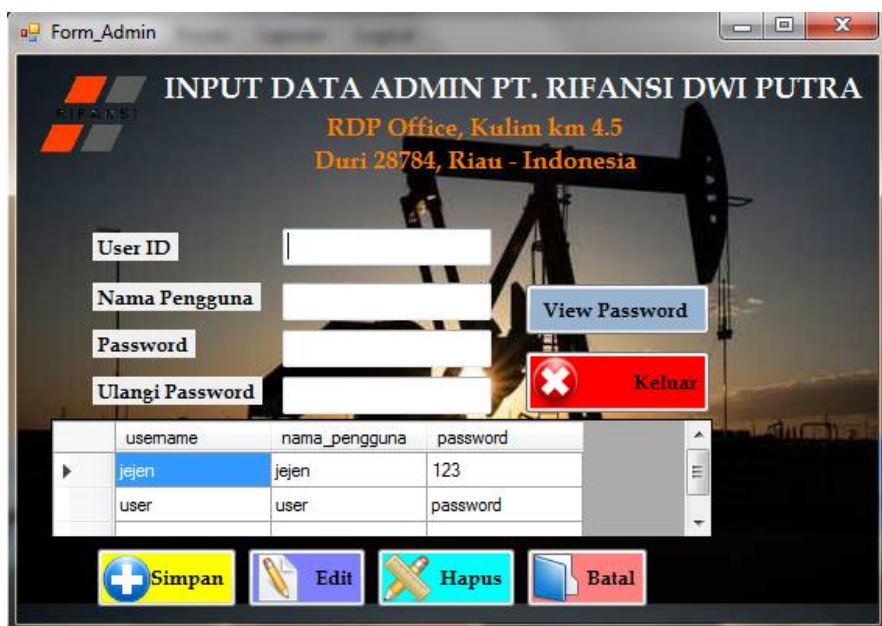

Figure 6. Admin Data

The uni data input form is shown in Figure 7 below.

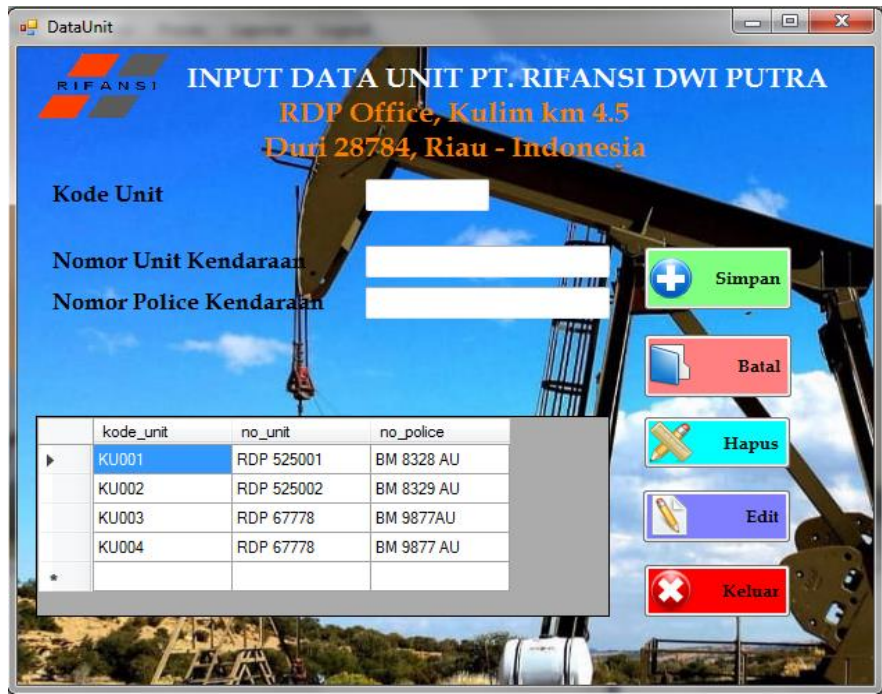

Figure 7. Input Data Unit 
The waste source data form is shown in Figure 8 below.

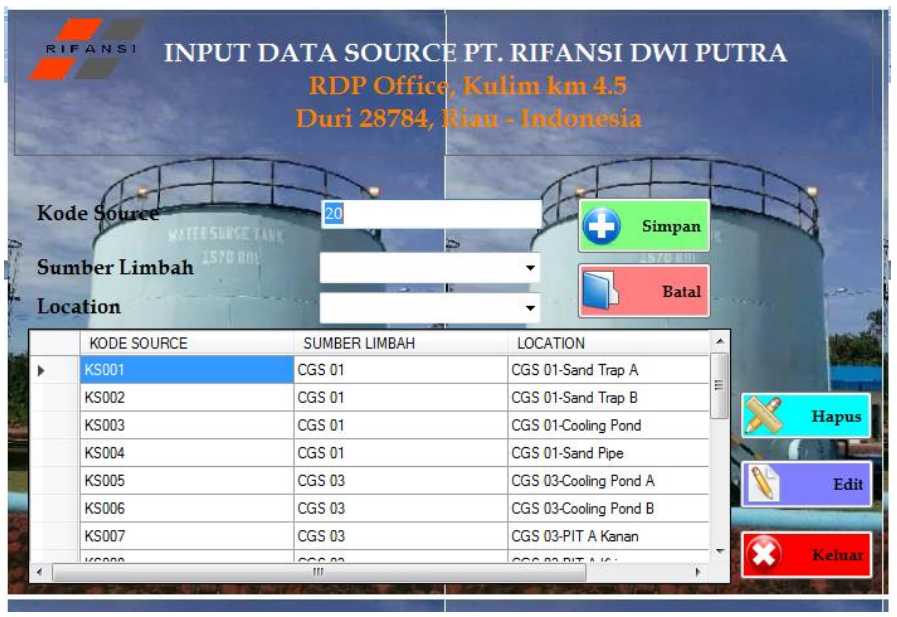

Figure 8. Waste Data Input

The waste data form is shown in Figure 9 below.

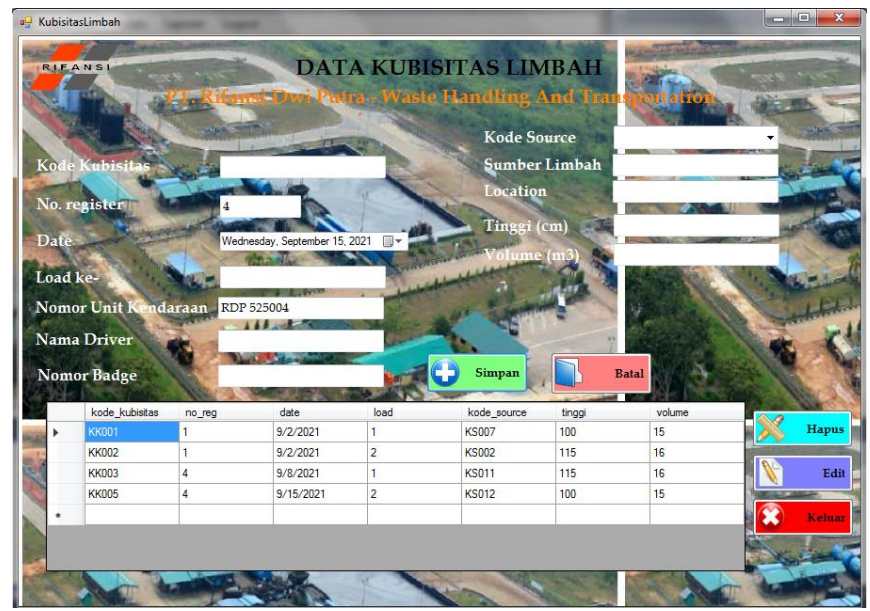

Figure 9. Waste Data

\subsection{Implementation and Unit Testing}

This stage is an activity to implement the design that has been designed into a programming language. Database settings are also carried out at this stage. Program coding is done based on application module units. After the coding process is made, the next step is to conduct unit testing to see if an error occurs. If there is an error, it will be corrected immediately.

Program coding as a whole using Visual Basic.Net applications. Visual Basic is an application program to quickly and easily create Microsoft Windows-based information systems [6]. The database in this study uses MySQL. MySQL is one of the database management systems to establish relationships between entities. It means that data management in the database will be stored in several different tables so that data manipulation can be done [7].

\subsection{System Integration}

This stage is a step to integrate all program units into one complete program. This integration relates to the ultimate goal of application design. After successfully implementing the system integration, the overall 
system testing is carried out. If an error is found, it is immediately corrected and then the test is carried out again until there are no more errors.

\subsection{Use and Maintenance}

The system is installed and put into daily use in the system use and maintenance phase. In addition, it also fixes errors that were not previously found at design time. At this maintenance stage, development of the system is also carried out, such as adding new features and functions [8] after designing the system using a new information system flow and applying it to program coding using visual basic, it produces a waste treatment application at PT. Rifansi Dwi Putra.

\section{Conclusion}

Based on the observations and analysis results during the research process at PT. Rifansi Dwi Putra, the researchers drew several conclusions, namely the system that was built can help reduce problems in data processing and reports on the volume of waste at PT. Rifansi Dwi Putra. This application can obtain better and optimal waste volume data collection information and minimize errors. The application designed to process waste volume data at PT. Rifansi Dwi Putra utilizes the Visual Basic.Net programming language and MySQL database well.

\section{References}

[1] H. Nopriandi, F. Teknik, U. Islam, K. Singingi, and T. Kuantan, "Perancangan sistem informasi registrasi mahasiswa," vol. 1, no. 1, pp. 73-79, 2018.

[2] K. C. Antasari, "Informasi Pada Kinerja Individual Dengan," E-Jurnal Akunt. Univ. Udayana, vol. 2, pp. 354-369, 2016.

[3] P. Limbah et al., "Pengelolaan Limbah B3 dan Keluhan Kesehatan Pekerja di PT. Inka (persero) Kota Madiun," pp. $118-127,2017$.

[4] I. G. S. Widharma, “Berbasis Web Dengan Metode SDLC,” pp. 38-41, 2017.

[5] Y. Firmansyah, "Penerapan Metode SDLC Waterfall Dalam Pembuatan Sistem Informasi Akademik Berbasis Web Studi Kasus Pondok Pesantren Al-Habi Sholeh Kabupaten Kubu Raya , Kalimantan Barat," vol. 4, no. 1, 2018.

[6] R. Irviani et al., "Aplikasi Perpustakaan Pada SMA N1 Kelumbayan Barat Menggunakan Visual Basic," vol. 8, no. 1, 2017.

[7] D. Menggunakan and P. H. P. Dan, “L e n t e r a d u m a i, , vol. 10, pp. 46-57, 2019.

[8] F. Fatmawati and J. Munajat, "Implementasi Model Waterfall Pada Sistem Informasi Persediaan Barang Berbasis Web," Media Inform. Budidarma, vol. 2, no. 2, pp. 1-9, 2018. 